\title{
SAMPLING TECHNIQUE FOR THRIPS IN VINEYARDS ${ }^{1}$
}

\author{
ANDRÉA NUNES MOREIRA², JOSÉ VARGAS DE OLIVEIRA ${ }^{3}$, \\ JOSÉ EUDES DE MORAIS OLIVEIRA ${ }^{4}$, JORGE BRAZ TORRES ${ }^{3}$, \\ GEISA MAYANA MIRANDA DE SOUZA ${ }^{5}$, SOLANGE MARIA DE FRANÇA ${ }^{6}$
}

ABSTRACT - In vineyards, thrips are listed as pests in many countries in continental Europe and the United States, attacking fruits, flowers, leaves and buds. In Brazil, many species have been reported in vineyards. This work aimed to evaluate the best technique and sampling unit, and the number of samples required in a conventional plan for sampling thrips in a vineyard. The studies were carried out in areas of Vitis vinifera, cultivar Sugraone, without application of insecticides. An area of $2.240 \mathrm{~m}^{2}$ was subjected to sample collection of leaves in different strata of 15 plants, and leaves on strata of branches for two subsequent years, totalizing 47 sampling dates. Furthermore, the sampling techniques of beating the inflorescence on a tray and whole inflorescence collection were also addressed. To calculate the sampling time, productive vineyards were used, with the varieties Sugraone and Thompson Seedless. Linear regressions of the relative densities as a function of absolute densities for thrips on branch per plant and leaves per branch were estimated. The technique of beating inflorescence on a tray was the one that best represented the results. The sampling unit that best represented the population was composed of one leaf collected from the median part of the branch. Thrips sampling should be conducted in 10 plants and 10 inflorescences per hectare to estimate the thrips population properly on plants and flowers, respectively.

Index terms: Vitis vinifera. Thysanoptera. Sampling unit. Integrated pest management.

\section{TÉCNICA DE AMOSTRAGEM CONVENCIONAL PARA TRIPES EM VIDEIRA}

RESUMO - Na cultura da videira, os tripes são mencionados como pragas em diversos países do continente Europeu e nos Estados Unidos, atacando frutos, flores, folhas e brotos. No Brasil, muitas espécies têm sido relatadas nesta cultura. Deste modo, o objetivo deste foi definir a melhor técnica, unidade amostral e o número de amostras exigidas em um plano convencional para a amostragem de tripes em uva. Os estudos foram realizados em áreas de Vitis vinifera, cultivar Sugraone, sem aplicação de inseticidas. Uma área de $2.240 \mathrm{~m}^{2}$ foi submetida a coleta de amostras em diferentes estratos de folhas e ramos, em 15 plantas, durante dois anos, totalizando 47 datas de amostragem. Além disso, também foram abordadas as técnicas de amostragem de batida da inflorescência na bandeja e coleta da inflorescência. Para o cálculo do tempo de amostragem foram utilizados parreirais com as variedades Sugraone e Thompson Seedless. Foram estimadas equações de regressões lineares entre as densidades relativas e absolutas de tripes por folha e ramo. A técnica da batida da flor foi a mais adequada para a amostragem dos tripes em inflorescências. A unidade amostral composta por uma folha localizada no meio do ramo mediano da planta foi o plano de melhor representatividade. A amostragem deve ser realizada em 10 plantas e 10 inflorescências por hectare para detectar os tripes na folha e na flor da videira, respectivamente.

Termos de indexação: Vitis vinifera. Thysanoptera. Unidade de amostragem. Manejo integrado de pragas.

(Paper 087-16) Received June 28, 2016. May 04, 2017.

${ }^{2}$ Teacher PhD. Instituto Federal de Educação, Ciência e Tecnologia do Sertão Pernambucano, Campus Petrolina Zona Rural, PetrolinaPE, Brazil. E-mail: andrea.nunes@ifsertao-pe.edu.br

${ }^{3}$ Teacher PhD. Department of Agronomy - Entomology, UFRPE, Recife, PE, Brazil. E-mail: vargasolievira@uol.com.br; jorge. torres@ufrpe.br

${ }^{4}$ Agronomist, PhD. Embrapa Semi-Arid, Petrolina, PE, Brazil. E-mail: jose.eudes@pq.cnpq.br

${ }^{5}$ Post-Graduate Program of the Federal University of Paraíba /UFPB. E-mail: geisamayana@yahoo.com.br

${ }^{6}$ Agronomist, Post-doctorate of the Post-Graduate Program in Agronomy-Tropical Agriculture / UFPI. E-mail: solangeufrpe@yahoo. com.br 


\section{INTRODUCTION}

In vineyards, thrips are listed as pests in many countries in continental Europe and the United States, attacking fruits, flowers, leaves and buds (DAKSHINA \& KUMAR, 2010; LOPES et al., 2002). In Brazil, Heliothrips haemorrhoidalis (Bouché), Retithrips syriacus Mayet, Frankliniella schultzei (Trybom) (MONTEIRO et al., 2001; MONTEIRO, 2002), Selenothrips rubrocinctus (Giard) (HAJI et al., 2001), Frankliniella rodeos (Moulton), Frankliniella gardeniae Moulton (BOTTON et al., 2007; BOTTON et al., 2015) and Frankliniella brevicaulis Hood (MOREIRA et al., 2012) have been reported in vineyards. In the lower mid São Francisco river valley locality, $S$. rubrocinctus, $R$. syriacus and Frankliniella sp. were identified as pests of fine grapes (HAJI et al., 2002; 2009), reducing fruit quality, especially for export markets.

Thrips cause more damage to vineyards during the flowering stage, coinciding with an increase in the population level (HAJI et al., 2009). The most significant damage occurs on clusters, with grapes presenting a whitish halo surrounding a small scar at the oviposition site for thrips Frankliniella (MOREIRA et al., 2014). The yellow spots on leaves, with possible necrosis and leaf-fall, resulting in partial or total defoliation of the plant, are the result of $S$. rubrocinctus and $R$. syriacus infestation (HAJI et al., 2009).

Chemical control is the main practice used by producers in the lower mid São Francisco river valley for thrips control (HAJI; ALENCAR, 2000). To reduce applications, programs for Integrated Pest Management (IPM) should be applied in commercial crops (KOGAN, 1998). In Brazil, the system of Integrated Fruit Production (IFP) was deployed in several crops, including vineyards, and has been reported to be responsible for a reduction of $89 \%$, on average, in the use of insecticides in the lower mid São Francisco river valley (OLIVEIRA et al., 2009). However, there is little information about techniques, decision-making and sampling plans concerning thrips in vineyards. Beating leaves or flowers in a tray, direct thrips counting on leaves, using sticky traps and Berlese funnel are techniques usually employed for evaluation of these insects in various crops (MUJICA et al., 2007; SEDARATIAN et al., 2010; PIZZOL et al., 2010; KAPLAN et al., 2016; SOUVIK SEN; SUIAM, 2016). Other techniques include washing panicles, immobilizing thrips with $\mathrm{CO}_{2}$ in plastic bags (ALIAKBARPOUR; RAWI, 2010) and using semiochemicals (ABDULLAH et al., 2015). In vineyards, Haji et al. (2001, 2009) recommended beating inflorescences in a whitecolored tray and direct counting in leaves for Frankliniella sp. and S. rubrocinctus respectively. Mujica et al. (2007) suggested the use of sticky traps for monitoring Frankliniella occidentalis (Pergande) in grapes, which could also be performed by striking its flowers.

The objectives of this research were to determine the spatial distribution of thrips in vineyards, to adjust a conventional sampling plan and to estimate the number of samples for decisionmaking, within a IPM context.

\section{MATERIAL AND METHODS}

The study was conducted at the Experimental Field of the Instituto Federal de Educação Ciência e Tecnologia do Sertão Pernambucano, Petrolina, PE $\left(09^{\circ} 20\right.$ '07.2"S and $\left.40^{\circ} 41^{\prime} 45.1^{\prime \prime} \mathrm{W}\right)$ in the semiarid region, with $537.3 \mathrm{~mm}$ average rainfall and annual average temperature ranging from $24^{\circ} \mathrm{C}$ to $28^{\circ} \mathrm{C}$ (MOURA et al., 2009).

Samples were taken from a four-hectare area of Vitis vinifera L. cv. Sugraone (seedless grape), 9 years old and $5.0 \times 3.5 \mathrm{~m}$ spacing, with two plants per hole. Within the vineyard, a 2,240 $\mathrm{m}^{2}$ area was delimited, corresponding to four rows of plans containing 64 plants/row. The area was not sprayed with insecticides or acaricides during the study period. Crop conditions were similar to those from a commercial area, except for the removal of shoot tips (shoot pruning), to evaluate new leaves until the end of the crop cycle. To calculate the sampling time, productive vineyards were used, with the varieties Sugraone and Thompson Seedless.

Thrips sampling in leaves. Leaf collection was performed at 15-day intervals, from 05/06/2008 to $06 / 02 / 2010$. Two leaves from apical, middle and basal positions of apical, middle and basal branches (totaling 6 leaves per branch) of 15 plants were randomly selected, in a methodology adapted from HAJI et al. (2001). The leaves were collected equidistantly, with leaves 1,3 and 5 from the righthand side of the branch and leaves 2, 4 and 6 from the left-hand side. The area was divided into five plots with three plants each within the same row and next to one another. Sampled leaves were packed in paper bags wrapped with plastic bags, labeled and taken to the Entomology Laboratory of Embrapa Semiárido for inspection. The number of larvae and adult thrips were counted under stereo microscope with 40x magnification. Thrips found alive were quantified, preserved in $70 \%$ ethanol and later sent 
for identification.

Thrips sampling in inflorescences. Two sampling techniques were investigated: beating in tray and inflorescence collection. The experimental area was subdivided into five plots of 10 plants each, collecting samples from one inflorescence per plant at stages of $100 \%$ flower bud, $40 \%$ and $100 \%$ open flowers, about 30,35 and 40 days after pruning, respectively. A white plastic tray $(30 \times 22 \times 7.5$ $\mathrm{cm})$ was used in the first sampling technique, over which five consecutive beats on the inflorescence were performed. Tray content was immediately placed inside $250 \mathrm{~mL}$ plastic containers with the aid of a wash bottle with $70 \%$ alcohol. Containers were capped, labeled and packed in a Styrofoam box. In the laboratory, samples were filtered in "TNT" fabric (non-woven fabric). Subsequently, thrips were counted, placed in $70 \%$ ethanol and samples were sent for identification.

For the second technique, inflorescences were harvested with the aid of shears and then placed in paper bags and packed in plastic bags. Afterwards, they were taken to the laboratory for further dissection and thrips counting.

Thrips samples from all samplings and sampling techniques were deposited in the Entomology Laboratory of Embrapa Semiárido and were sent to Dr. Renata C. Monteiro and Adriano Cavalleri (Federal University of Rio Grande) for identification.

Sampling unit selection. To select the sampling unit to be used for sampling thrips, the criteria of representativeness, precision and speed were used.

In the representativeness criterion, sampling units were selected that showed significant correlations between relative and absolute densities of the number of thrips on leaves and branches. For such, the linear regression model was used that best fitted the data and with the highest values for the model's angular coefficient according to Gusmão et al. (2005). In this study, selected models had significant coefficients at $1 \%$ probability for branches and $5 \%$ probability for leaves.

The selection of sampling units based on the accuracy criterion considered the relative variance, based on variances below $25 \%$ as recommended by Southwood (1978). Thrips densities for sampling units were obtained by combining branches and leaves. The most representative and accurate sampling units, but which resulted in fewer numbers of branches and leaves to be sampled, were selected for the speed criterion.

The times for collection and counting of thrips on branches and leaves were recorded using a chronometer and formed by the combination, in sequence, of one to six leaves from one to three branches per plant. For this, evaluations were made in seven grape-growing areas, of which two were in the shooting phase (Areas 1 of 4,2 ha and 2 of 4,0 ha), two in the resting phase (Areas 3 of 2,24 ha and 4 of 4,3 ha), two near to harvest time (Areas 5 of 3,094 ha and 6 of 3,9 ha), and one in the vegetative growth phase (Area 7 of 4,8 ha). Areas 1, 2, 5 and 7 used Thompson Seedless variety. Ten plants were sampled per area, using the zig-zag pathway, taking one branch in apical, median and basal positions on the plant, collecting six leaves per branch, of which two were for each of the apical, median and basal positions. The time spent on the pathway for sample collection was not considered.

Determination of the Sampling Technique.

To select the best thrips sampling technique for inflorescences, the means and standard errors of the insects densities were calculated, which were used to estimate the relative variance, according to Pedigo et al. (1982) and Pedigo and Rice (2009). The relative variance measures the sample data variability, and the best systems are those with lower values for this parameter. Moreover, the technique selected was that showing significant correlations between relative and absolute densities for the number of thrips on inflorescences, the highest coefficient of determination in linear regression analysis $\left(r^{2}\right)$ and significance at $1 \%$ probability.

To calculate the sampling cost, the following were taken into consideration: the sampler's salary, social security charges and the cost of sampling materials, such as pencil and paper. For the inflorescence collection technique, in addition to the expenses already mentioned, the cost of a stereo microscope (useful life x equipment depreciation), facilities (laboratory), plastic bags, thinning scissors, marker pen, stylus, brush, Petri dish and the cost of a bunch of grapes were used. In the inflorescence beating technique the costs of the clipboard, pocket magnifying glass and a white plastic tray, alcohol, wash bottle and plastic container $(250 \mathrm{~mL})$ for packaging thrips were added to the value.

The time for sample collection was simulated by an hours/man coefficient, considering 10 samples for each sampling technique. Estimates for the walking time and sample processing time in the laboratory were the same as those used for leaf collection.RVR) were calculated the economic accuracies (PE) for sample systems, using the equation: $\mathrm{PE}=100 /(\mathrm{Ca} \times \mathrm{VR})(\mathrm{KOGAN}$; HERZOG, 1980). The economic accuracy indicates the best 
sampling system based on variability and sample cost, and the best systems are those with the highest values in relation to this feature.

Number of Samples. The number of samples to be taken was estimated using the formula proposed by Kogan and Herzog (1980), which is applied when the spatial distribution is contagious. The number of plants recommended for sampling thrips (larvae + adults) on leaves and inflorescences was determined by assuming the real sampling values for the agricultural cycles of one and two vineyards, respectively, ignoring values less than one.

The number of samples for inflorescences was determined, considering the levels of precision and suitability for IPM and based on the assessment of the relative variance and economic precision. These parameters were calculated with simulated data of real samples in different combinations of sample sizes (10 to 40) for assessments at 40 and $100 \%$ open flowers.

Statistical Analysis. Means, standard errors and $95 \%$ confidence intervals were obtained using the PROC MEANS and the correlation and angular regression coefficients, using the PROC REG (SAS INSTITUTE, 2001). The average number of thrips on leaves and branches and the sampling time were evaluated by analyses of variance and Tukey test at $5 \%$ significance. Original data on the average number of thrips were square root transformed $(x+0.5)$ to meet the assumptions for analyses of variance. Distributions were calculated using Excel spreadsheets. Relative variance was calculated using the formula of Southwood (1978): VR $=(100 * E P) / x$, where $\mathrm{VR}=$ relative variance, $\mathrm{EP}=$ standard error of the mean and $x=$ mean.

\section{RESULTS AND DISCUSSION}

Of the 13,153 individuals collected in vine leaves in the experimental area, 1,368 were adults and 11,785 were larvae. The phytophagous adults species identified were $R$. syriacus $(78.95 \%), H$. haemorrhoidalis $(13.89 \%)$, S. rubrocinctus $(0.44 \%)$, F. schultzei and Frankliniella sp (5.41\%). The predatory species Scolothrips sp was found with $1.31 \%$. In inflorescences, the species collected were $F$. schultzei, $F$. brevicaulis, $F$. rodeos, $F$. gardeniae and Frankliniella sp, totaling 2,115 individuals adults. A complex of thrips species exists that can infest both leaves and inflorescences of grapevines, and this may occur in different phenological phases, with a greater infestation in the flowering phase and near to harvest. However, in the lower mid São Francisco river valley region, the species $R$. syriacus occurs predominantly on leaves and the genus Frankliniella on inflorescences (MOREIRA et al., 2012), which leads to commercial devaluation of the fruit and loss in grapevine yield (MOREIRA et al., 2014).

Sampling unit Selection. According to the analysis of variance there was no statistical difference between the number of thrips (larvae + adults $)$ and the plant's branch position $\left(\mathrm{F}_{212,687}=\right.$ $0.26, \mathrm{P}=0.7684$ ), with averages ranging from 1.02 to 1.06 thrips per branch. This was possibly because the samplings were carried out on vines being grown in the "pergola" system, where the branches of the plant develop horizontally and are arranged at the same height. This system is used more than the vertical "trellis" for producing fine table grapes in the Brazilian Northeast Este. Mujica et al. 2007 observed a larger population of $F$. occidentalis on inflorescences in the "lyre-shaped" system for vines $(0.38 \%)$ than in the vertical trellis $(0.12 \%)$.

Thrips densities (larvae + adults) observed in the sampling units composed of branches in the three plant thirds and their combinations were representative, with branches at positions 2 and 6 selected due to their larger angular coefficient in the group with one and two branches, respectively (Table 1). By the accuracy criterion, all branches and their combinations were selected, presenting $25 \%$ relative variance. However, sampling units composed of the lowest number of branches obtained the lowest sampling times. Concerning frequency, all branch positions and their combinations were selected, because they were always present in the plants during the sampling period. Thus, the branch in the median position meets all the criteria for sampling unit selection, which is indicated in the survey of thrips populations in vineyards.

Average larvae densities on basal, middle and apical branches were $0.95,0.92$ and 0.91 , respectively. For adults it was 0.11 on basal and medial branches and 0.10 for the apical branch. The fact of finding larvae and adults shows that the plant is a suitable host for oviposition and thrips development.

Leaf position 4 in the branches was the one with the highest density of larvae + adults per leaf $(1.65 \pm 0.22)\left(\mathrm{F}_{5,12687}=15.34, \mathrm{P}<0.0001\right)$, regardless of basal, middle or apical branch position. The leaf at position 3 with a mean of $1.44 \pm 0.18$ thrips did not differ from the leaf at position 4 (Table 2). The leaves at positions 3 until 6 and 8 until 62 were selected because they had a positive and significant correlation between the relative (thrips/leaf) and absolute (thrips/plant) densities (Table 3). Based 
on the relative variance, all leaf positions on the branches and their combinations exhibited less than $25 \%$, being considered suitable for thrips sampling. Concerning sampling time, leaves at positions 1-6, composed of a single sampling unit, differed significantly from other combinations (Table 3 ).

Leaf positions and their combinations had $100 \%$ presence on the branch. However, sampling units at leaf positions 5 and 6 , located at the end of the branch, may not be present, thus not considered ideal for sampling. This is due to branch pruning practice adopted in the lower mid São Francisco river valley, which involves removing shoot tips (Leão \& Rodrigues, 2009). As the work was conducted in an experimental area, and the goal was to determine the best sampling unit, this cultural treatment was not performed. Therefore, the leaf at position 3 or 4 was considered the best sampling unit to assess thrips (larvae + adults) at all vine phenological stages.

Average densities of thrips larvae in leaves at positions $1,2,3,4,5$, and 6 were $0.86,0.90,1.31$, $1.47,0.54$ and 0.48 ; while for adults values were 0.11 , $0.11,0.13,0.17,0.06$ and 0.07 at positions $1,2,3,4,5$ and 6, respectively (Table 2). Results showed a higher thrips population in the intermediate leaves (larvae and adults). This difference in infestation between leaves of different ages may affect oviposition, growth and development of these insects (KOGEL et al., 1997a, b). Bacci et al. (2008) explained that thrips infestation on young or old leaves is a result of the morphological, chemical and nutritional characteristics of the plant. They also observed that the population density of $F$. shultzei was higher in young cucumber leaves. Similar results were obtained by Seal et al. (2006), who found a larger population of Scirtothrips dorsalis Hood on apical leaves of sweet pepper compared to middle and lower leaves.

According to our results, thrips sampling (larvae + adults) should be performed with the leaf at position 3 or 4 , located in the middle of the vine's medial branch. Haji et al. (2009) recommend the sampling of three leaves per branch at three branches per plant, whereas in the present study the sampling of one leaf per plant is suggested. Thus, there will be a reduction in sampling time and manpower, which may affect decision-making on whether to control thrips or not.

Sampling technique determination. The number of thrips collected varied significantly in the two techniques tested (Table 4). The inflorescence collection showed a greater population density of thrips larvae and adults and a higher coefficient of determination $\left(r^{2}\right)$ when compared with the technique of beating the flowers. The relative variance was less than $25 \%$ for both techniques. However, considering time, cost and accuracy of sampling, beating inflorescences was more representative (Table 4). This occurred because inflorescence collection requires a higher number of operations (cutting, sacking, flower removal from the bag, dissection and counting of thrips under stereo microscope). Thus, beating inflorescences can be considered a suitable technique for sampling larval and adult thrips on vine inflorescences. Mujica et al. (2007) also used this technique in the detection of $F$. occidentalis in vine inflorescences. However, Botton et al. (2007) found no difference among the number of $F$. rodeos collected on vines in both techniques.

It was observed that in the first year of study, using the three assessments (when the floral bud was closed, with $40 \%$ and $100 \%$ of flowers open), the number of larvae + adults of thrips were 3, 98 and 173 for the inflorescence beating technique and 45, 206 and 531 for the inflorescence collection, respectively. In the second year, the thrips population was 15, 69 and 149 for the inflorescence beating technique, and 35, 267 and 1069 for the inflorescence collection, respectively. These results demonstrated that as the flower buds open, the thrips population increases. This has also been reported by Mateus et al. (2005), who found a more abundant population of $F$. occidentalis in flowers than in carnation flower buds. According to González (1999), thrips are attracted when flowering begins, and females penetrate the calyptras fissures when they are still on the stamens and pistils of flowers, to lay eggs in the ovary wall. The relationship between the flowering stage and thrips abundance shows the attraction of pollen as a food source in the grape crop (MUJICA et al., 2007). The size of the inflorescence may also influence the thrips population, as observed in $V$. vinifera (MUJICA et al., 2007) and Polianthes tuberosa L (ARCE-FLORES et al., 2014), for the species $F$. occcidentalis, with a mean number of 100.0 and 123.65 individuals per flower, respectively.

As the thrips population remained high even with $100 \%$ open flowers, it is recommended that sampling should be continued until the fruit set (pellet-like berries). This sampling period is the same as that indicated by Haji et al. $(2001,2009)$.

Number of samples. Estimates of sample size for the number of plants and inflorescences varied according to the accuracy level used (Table $5)$. The results suggest that an accuracy level between 20 and $25 \%$ can be adopted for plants (leaves), corresponding respectively to 10 and 7 leaves to be sampled in 1.0 hectare. In the case of inflorescences, 
considering 20 and $25 \%$ accuracy level, 83 and 53 samples, respectively, are necessary in 1.0 hectare.

Following this information, the thrips sampling process in the inflorescence currently performed in the lower mid São Francisco river valley would be very expensive, because population monitoring is performed three times a week, due to the pest's biological characteristics and the vine flowering stage. According to Carrizo and Klasman (2002), when it comes to studies for scientific purposes, the appropriate sample size depends on the slightest effort to perform the sampling to meet the statistical requirements. However, in the case of commercial crops, the authors considered the additional sampling cost and therefore reduced the accuracy level to $25 \%$ when calculating the number of samples for adults of $F$. occidentalis on flowers of Dianthus caryophyllus L. Other studies related to determining the accuracy level were also developed by Seal et al. (2006), who used a level of $40 \%$ to determine the number of samples for adults of S. dorsalis on pepper leaves; Mujica et al. (2007) adopted $25 \%$ accuracy level for $F$. occidentallis in $D$. caryophyllus, totaling 30 flowers for sampling adults and 75 for larvae. Parajule et al. (2006) adopted a $25 \%$ accuracy level to sample $T$. palmi in potato leaves and F. occidentallis in cotton, respectively.

According to Southwood (1978), the relative variance can be used to determine the number of samples in the assessment of insects' population density. In the most extensive studies, such as IPM, the author used up to $25 \%$ relative variance, while for research studies variance must be up to $10 \%$. Another criterion to be analyzed is the economic precision, since sampling cost becomes a limiting factor in deploying IPM programs. Based on these observations, it is possible to estimate reliably the number of samples to be used in a sampling plan by calculating the relative variance and the economic precision. In Table 6 are the values of relative variance and economic precision obtained in simulated samplings of thrips in the inflorescence, using actual data obtained from samplings performed in two grapevine production cycles at the flowering stage with 40 and $100 \%$ open flowers. It is observed that the number of 10 samples can be accurately and cost-effectively recommended for estimating thrips population during vine inflorescence, because it presented the highest value of economic accuracy.

It is noted that this number of samples is equal to that recommended for the Submédio do Vale do São Francisco, 10 inflorescence per sample (HAJI et al., 2001, 2009). This recommendation aims mainly to avoid increasing the time and therefore the sampling cost, since, given the accuracy levels of 25 and $40 \%$, it would be necessary to have 53 to 20 samples per hectare, respectively (Table 5). However, according to the recommendation based on the relative variance and economic precision (Table 6 ), the number of samples can be reduced to 10 inflorescences per hectare, if sampling starts before the buds open and continues until the fruit is set.

Given these considerations, the sample size must be in parsimony with the practicality of monitoring, while maintaining accuracy in obtaining the sample estimates. From the results obtained, it is expected that thrips sampling can be performed based on scientific criteria, aiming for the vineyard's sustainability. This information is essential to the success of a conventional sampling plan in the context of an integrated production of fine grapes in the lower mid São Francisco river valley. 
TABLE 1-Mean $( \pm$ SE) on number of thrips (larvae + adults) per branch position in the plant, relative variance (RV), probability significance $(P)$, correlation coefficient $\left(r^{2}\right)$, angular coefficient $(b)$ between relative (thrips/branch) absolute densities (thrips/branch) and average time (sec) of thrips sampling in vineyards, cultivar Sugraone and Thompson Seedless. Petrolina, PE, 2008 to 2010.

\begin{tabular}{cccccccccc}
\hline $\begin{array}{c}\text { Branch } \\
\text { number }\end{array}$ & $\begin{array}{c}\text { Branch position } \\
\text { in the plant }\end{array}$ & $\mathrm{N}^{1}$ & $\mathrm{n}^{2} \begin{array}{c}\text { Number of thrips } \\
(\text { Mean } \pm \mathrm{SE})^{3}\end{array}$ & $\begin{array}{c}\mathrm{VR} \\
(\%)\end{array}$ & $r^{2}$ & $P$ & $b$ & $\begin{array}{c}\text { Time in } \\
\text { seconds } \\
(\text { Mean } \pm \mathrm{EP})^{4}\end{array}$ \\
\hline 1 & Apical & 1 & 6 & $6.4 \pm 0.59$ & 9.22 & $0.3185^{*}$ & 0.0284 & 0.22959 & $246.5 \pm 9.72 \mathrm{a}$ \\
2 & Median & 1 & 6 & $6.2 \pm 0.73$ & 11.77 & $0.7019^{* *}<0.0001$ & 0.42112 & $235.5 \pm 9.93 \mathrm{a}$ \\
3 & Basal & 1 & 6 & $6.1 \pm 0.70$ & 11.47 & $0.5335^{* *}$ & 0.0020 & 0.34928 & $237.5 \pm 9.75 \mathrm{a}$ \\
\hline 4 & Apical and Median & 2 & 12 & $12.5 \pm 1.06$ & 8.48 & $0.7988^{* *}<0.0001$ & 0.65072 & $482.0 \pm 18.60 \mathrm{~b}$ \\
5 & Apical and Basal & 2 & 12 & $12.5 \pm 0.94$ & 7.52 & $0.8165^{* *}<0.0001$ & 0.57888 & $484.0 \pm 18.17 \mathrm{~b}$ \\
6 & Median and Basal & 2 & 12 & $12.3 \pm 1.23$ & 10.00 & $0.8403 * *<0.0001$ & 0.77041 & $473.0 \pm 18.51 \mathrm{~b}$
\end{tabular}

'Number of branches sampled per plant

${ }^{2}$ Number of leaves sampled per branch.

${ }^{3}$ Average number of thrips sampled on 47 evaluations, 15 plants per evaluation.

${ }^{4}$ Average time in seconds sampled at 70 plants. Means followed by same letter in column do not differ by the Tukey test $(\mathrm{P}>0.05)$.

*Significant at $5 \%$ probability. **Significant at $1 \%$ probability.

TABLE 2- Average number of thrips (larvae + adults) and 95\% confidence interval (CI) at different leaf positions in the vineyard branch, cultivar Sugraone. Petrolina, PE. 2008 to 2010.

\begin{tabular}{cccccc}
\hline $\begin{array}{c}\text { Leaf position } \\
\text { in the branch }\end{array}$ & $\mathrm{n}^{1}$ & $\begin{array}{c}\text { Mean thrips } \\
+ \text { larvae } \pm \mathrm{SE}^{2}\end{array}$ & $\begin{array}{c}\text { Mean thrips } \\
+ \\
\text { adults } \pm \mathrm{SE}^{2}\end{array}$ & $\begin{array}{c}\text { Mean thrips (larvae }+ \text { adults) } \\
\pm \mathrm{SE}^{2}\end{array}$ & $95 \% \mathrm{CI}$ \\
\hline 1 & 2.115 & $0.86 \pm 0.10$ & $0.11 \pm 0.01$ & $0.98 \pm 0.11 \mathrm{~b}$ & $0.22-1.73$ \\
2 & 2.115 & $0.90 \pm 0.12$ & $0.11 \pm 0.01$ & $1.01 \pm 0.13 \mathrm{~b}$ & $0.25-1.76$ \\
3 & 2.115 & $1.31 \pm 0.16$ & $0.13 \pm 0.02$ & $1.44 \pm 0.18 \mathrm{ab}$ & $0.34-2.54$ \\
4 & 2.115 & $1.47 \pm 0.21$ & $0.17 \pm 0.02$ & $1.65 \pm 0.22 \mathrm{a}$ & $0.43-32.87$ \\
5 & 2.115 & $0.54 \pm 0.09$ & $0.06 \pm 0.01$ & $0.60 \pm 0.09 \mathrm{c}$ & $0.18-1.01$ \\
6 & 2.115 & $0.48 \pm 0.09$ & $0.07 \pm 0.01$ & $0.55 \pm 0.10 \mathrm{c}$ & $0.20-0.89$ \\
\hline
\end{tabular}

${ }^{1}$ Number of units sampled in 47 evaluations.

${ }^{2}$ Means followed by same letter in the column differ by the Tukey test $(\mathrm{P}<0.01)$. 
TABLE 3-Mean number of thrips (larvae + adults) per leaf position on vineyard, cultivar Sugraone, relative variance $(\mathrm{RV})$, probability significance $(P)$, correlation coefficient $\left(r^{2}\right)$, angular coefficient (b) between relative (thrips/leaf) and absolute densities (thrips/plant) and the average time in seconds of thrips sampling on vineyards, Sugraone and Thompson Seedless cultivar. Petrolina, PE, 2008 to 2010 .

\begin{tabular}{|c|c|c|c|c|c|c|c|c|}
\hline $\begin{array}{c}\text { Leaf } \\
\text { number }\end{array}$ & $\begin{array}{l}\text { Leaf position } \\
\text { in the branch }\end{array}$ & $\mathrm{n}^{1}$ & $\begin{array}{c}\text { Number } \\
\text { of thrips } \\
\left(\text { mean } \pm \mathrm{SE}^{2}\right)\end{array}$ & RV (\%) & $r^{2}$ & $P$ & $b$ & $\begin{array}{l}\text { Time in seconds } \\
\left(\text { mean } \pm \mathrm{SE}^{2}\right)^{3}\end{array}$ \\
\hline 1 & 1 & 3 & $2.9 \pm 0.29$ & 10.00 & 0.1668 & 0.1307 & 0.07992 & $42.8 \pm 1.35 \mathrm{a}$ \\
\hline 2 & 2 & 3 & $3.0 \pm 0.29$ & 9.67 & 0.0096 & 0.7284 & 0.01961 & $39.8 \pm 1.29 \mathrm{a}$ \\
\hline 3 & 3 & 3 & $4.3 \pm 0.47$ & 10.93 & $0.6450 * *$ & 0.0003 & 0.25798 & $43.9 \pm 1.43 \mathrm{a}$ \\
\hline 4 & 4 & 3 & $4.9 \pm 0.71$ & 14.49 & $0.4815^{* *}$ & 0.0041 & 0.33411 & $42.5 \pm 1.28 \mathrm{a}$ \\
\hline 5 & 5 & 3 & $1.8 \pm 0.40$ & 22.22 & $0.4149 * *$ & 0.0005 & 0.17615 & $37.3 \pm 1.16 \mathrm{a}$ \\
\hline 6 & 6 & 3 & $1.6 \pm 0.33$ & 20.63 & $0.3423^{*}$ & 0.0220 & 0.13222 & $33.6 \pm 1.01 \mathrm{a}$ \\
\hline 7 & 1 e 2 & 6 & $5.9 \pm 0.45$ & 7.63 & 0.1076 & 0.2327 & 0.09953 & $82.5 \pm 2.30 \quad b$ \\
\hline 8 & 1 e 3 & 6 & $7.2 \pm 0.59$ & 8.19 & $0.7149 * *$ & $<0.0001$ & 0.33791 & $86.7 \pm 2.43 \quad b$ \\
\hline 9 & $1 \mathrm{e} 4$ & 6 & $7.9 \pm 0.75$ & 9.49 & $0.6542 * *$ & 0.0003 & 0.41404 & $78.6 \pm 2.08 \mathrm{~b}$ \\
\hline 10 & 1 e 5 & 6 & $4.7 \pm 0.56$ & 11.91 & $0.4442 * *$ & 0.0067 & 0.25608 & $80.1 \pm 2.10 \quad b$ \\
\hline 11 & 1 e 6 & 6 & $4.6 \pm 0.50$ & 10.87 & $0.3940^{*}$ & 0.0122 & 0.21214 & $76.4 \pm 1.95 \mathrm{~b}$ \\
\hline 12 & 2 e 3 & 6 & $7.3 \pm 0.56$ & 7.67 & $0.5276^{* *}$ & 0.0022 & 0.27759 & $83.7 \pm 2.42 b$ \\
\hline 13 & 2 e 4 & 6 & $8.0 \pm 0.70$ & 8.75 & $0.5534 * *$ & 0.0015 & 0.35372 & $82.2 \pm 2.27 \quad b$ \\
\hline 14 & 2 e 5 & 6 & $4.8 \pm 0.50$ & 10.42 & $0.3357^{*}$ & 0.0236 & 0.19576 & $77.0 \pm 2.13 \quad b$ \\
\hline 15 & 2 e 6 & 6 & $4.7 \pm 0.42$ & 8.94 & $0.2874 *$ & 0.0394 & 0.15183 & $73.3 \pm 1.93 \quad b$ \\
\hline 16 & 3 e 4 & 6 & $9.3 \pm 1.10$ & 11.83 & $0.6321 * *$ & 0.0004 & 0.59210 & $86.4 \pm 2.38 \quad b$ \\
\hline 17 & 3 e 5 & 6 & $6.1 \pm 0.68$ & 11.15 & $0.8840 * *$ & $<0.0001$ & 0.43414 & $81.2 \pm 2.22$ \\
\hline 18 & 3 e 6 & 6 & $6.0 \pm 0.64$ & 10.67 & $0.8100 * *$ & $<0.0001$ & 0.39020 & $77.5 \pm 2.00$ \\
\hline 19 & 4 e 5 & 6 & $6.7 \pm 0.85$ & 12.69 & $0.7760 * *$ & $<0.0001$ & 0.51027 & $79.8 \pm 2.01$ \\
\hline 20 & 4 e 6 & 6 & $6.6 \pm 0.80$ & 12.12 & $0.7426^{* *}$ & $<0.0001$ & 0.46633 & $76.1 \pm 1.90$ \\
\hline 21 & 5 e 6 & 6 & $3.4 \pm 0.71$ & 20.88 & $0.4124 * *$ & 0.0098 & 0.30837 & $70.9 \pm 1.95$ \\
\hline 22 & 1,2 and 3 & 9 & $10.3 \pm 0.68$ & 6.60 & $0.5909 * *$ & 0.0008 & 0.35752 & $126.5 \pm 3.40$ \\
\hline 23 & 1,2 and 4 & 9 & $10.9 \pm 0.76$ & 6.97 & $0.6964 * *$ & $<0.0001$ & 0.43364 & $125.0 \pm 3.26 \mathrm{c}$ \\
\hline 24 & 1,2 and 5 & 9 & $7.7 \pm 0.66$ & 8.57 & $0.3787 *$ & 0.0146 & 0.27569 & $119.8 \pm 3.07 \mathrm{c}$ \\
\hline 25 & 1,2 and 6 & 9 & $7.6 \pm 0.58$ & 7.63 & $0.3419^{*}$ & 0.0221 & 0.23175 & $116.1 \pm 2.89$ \\
\hline 26 & 1,3 and 4 & 9 & $12.2 \pm 1.14$ & 9.34 & $0.7489 * *$ & $<0.0001$ & 0.67202 & $129.2 \pm 3.36$ \\
\hline 27 & 1,3 and 5 & 9 & $9.0 \pm 0.81$ & 9.00 & $0.8685^{* *}$ & $<0.0001$ & 0.51406 & $124.0 \pm 3.17 \mathrm{c}$ \\
\hline 28 & 1,3 and 6 & 9 & $8.9 \pm 0.76$ & 8.54 & $0.8206^{* *}$ & $<0.0001$ & 0.47013 & $120.3 \pm 2.97 \mathrm{c}$ \\
\hline 29 & 1,4 and 5 & 9 & $9.7 \pm 0.93$ & 9.59 & $0.8702 * *$ & $<0.0001$ & 0.59019 & $115.9 \pm 2.67 \mathrm{c}$ \\
\hline 30 & 1,4 and 6 & 9 & $9.5 \pm 0.87$ & 9.16 & $0.8578 * *$ & $<0.0001$ & 0.54626 & $112.2 \pm 2.49$ \\
\hline 31 & 1,5 and 6 & 9 & $6.4 \pm 0.84$ & 13.13 & $0.4593 * *$ & 0.0055 & 0.38830 & $113.7 \pm 2.80$ \\
\hline 32 & 2,3 and 4 & 9 & $12.3 \pm 1.09$ & 8.86 & $0.6782 * *$ & 0.0002 & 0.61170 & $126.5 \pm 3.6$ \\
\hline
\end{tabular}

continued... 


\begin{tabular}{|c|c|c|c|c|c|c|c|c|}
\hline 33 & 2,3 and 5 & $99.1 \pm 0.74$ & 8.13 & $0.8062 * *$ & $<0.0001$ & 0.45374 & $120.9 \pm 3.20$ & $\mathrm{~cd}$ \\
\hline 34 & 2,3 and 6 & $99.0 \pm 0.69$ & 7.67 & $0.7637 * *$ & $<0.0001$ & 0.40981 & $117.6 \pm 3.0$ & $\mathrm{~cd}$ \\
\hline 35 & 2,4 and 5 & $99.8 \pm 0.84$ & 8.57 & $0.8531 * *$ & $<0.0001$ & 0.52987 & $119.5 \pm 3.02$ & $\mathrm{~cd}$ \\
\hline 36 & 2,4 and 6 & $99.6 \pm 0.77$ & 8.02 & $0.8551 * *$ & $<0.0001$ & 0.48594 & $115.8 \pm 2.86$ & $\mathrm{~cd}$ \\
\hline 37 & 2,5 and 6 & $96.5 \pm 0.75$ & 11.54 & $0.4153 * *$ & 0.0095 & 0.32798 & $110.6 \pm 2.83$ & $\mathrm{c}$ \\
\hline 38 & 3,4 and 5 & $911.0 \pm 1.23$ & 11.18 & $0.8509 * *$ & $<0.0001$ & 0.76825 & $123.7 \pm 3.09$ & $\mathrm{~cd}$ \\
\hline 39 & 3,4 and 6 & $910.9 \pm 1.19$ & 10.92 & $0.8079 * *$ & $<0.0001$ & 0.72431 & $120.0 \pm 2.92$ & $\mathrm{~cd}$ \\
\hline 40 & 3,5 and 6 & $97.7 \pm 0.93$ & 11.92 & $0.7964 * *$ & $<0.0001$ & 0.56636 & $114.8 \pm 2.88$ & $\mathrm{~cd}$ \\
\hline 41 & 4,5 and 6 & $98.4 \pm 1.04$ & 12.38 & $0.8235^{* *}$ & $<0.0001$ & 0.64248 & $113.3 \pm 2.73$ & $\mathrm{~cd}$ \\
\hline 42 & $1,2,3$ and 4 & $1215.2 \pm 1.15$ & 7.57 & $0.7792 * *$ & $<0.0001$ & 0.69163 & $168.9 \pm 4.34$ & $\mathrm{e}$ \\
\hline 43 & $1,2,3$ and 5 & $1212.1 \pm 0.88$ & 7.27 & $0.7908 * *$ & $<0.0001$ & 0.53367 & $163.7 \pm 4.15$ & e \\
\hline 44 & $1,2,3$ and 6 & $1211.9 \pm 0.83$ & 6.97 & $0.7614 * *$ & $<0.0001$ & 0.48973 & $160.1 \pm 3.93$ & $\mathrm{e}$ \\
\hline 45 & $1,2,4$ and 5 & $1212.7 \pm 0.94$ & 7.40 & $0.9124 * *$ & $<0.0001$ & 0.60980 & $162.3 \pm 3.98$ & e \\
\hline 46 & $1,2,4$ and 6 & $1212.5 \pm 0.86$ & 6.88 & $0.9283 * *$ & $<0.0001$ & 0.56586 & $158.6 \pm 3.82$ & $\mathrm{e}$ \\
\hline 47 & $1,2,5$ and 6 & $129.4 \pm 0.90$ & 9.57 & $0.4492 * *$ & 0.0063 & 0.40790 & $153.4 \pm 3.73$ & $\mathrm{e}$ \\
\hline 48 & $1,3,4$ and 5 & $1214.0 \pm 1.30$ & 9.29 & $0.9264 * *$ & $<0.0001$ & 0.84817 & $166.5 \pm 4.06$ & $\mathrm{e}$ \\
\hline 49 & $1,3,4$ and 6 & $1213.8 \pm 1.25$ & 9.06 & $0.8951 * *$ & $<0.0001$ & 0.80424 & $162.8 \pm 3.89$ & $\mathrm{e}$ \\
\hline 50 & $1,3,5$ and 6 & $1210.7 \pm 1.06$ & 9.91 & $0.8053 * *$ & $<0.0001$ & 0.64628 & $157.6 \pm 3.79$ & $\mathrm{e}$ \\
\hline 51 & $1,4,5$ and 6 & $1211.3 \pm 1.13$ & 10.00 & $0.8832 * *$ & $<0.0001$ & 0.72241 & $156.2 \pm 3.65$ & e \\
\hline 52 & $2,3,4$ and 5 & $1214.1 \pm 1.22$ & 8.65 & $0.8997 * *$ & $<0.0001$ & 0.78786 & $163.4 \pm 4.09$ & $\mathrm{e}$ \\
\hline 53 & $2,3,4$ and 6 & $1213.9 \pm 1.17$ & 8.42 & $0.8709 * *$ & $<0.0001$ & 0.74392 & $159.7 \pm 3.90$ & $\mathrm{e}$ \\
\hline 54 & $2,3,5$ and 6 & $1210.8 \pm 0.97$ & 8.98 & $0.7912 * *$ & $<0.0001$ & 0.58596 & $154.5 \pm 3.83$ & $\mathrm{e}$ \\
\hline 55 & $2,4,5$ and 6 & $1211.4 \pm 1.02$ & 8.95 & $0.9059 * *$ & $<0.0001$ & 0.66209 & $153.1 \pm 3.68$ & $\mathrm{e}$ \\
\hline 56 & $3,4,5$ and 6 & $1212.7 \pm 1.39$ & 10.94 & $0.9080 * *$ & $<0.0001$ & 0.90047 & $157.3 \pm 3.73$ & e \\
\hline 57 & $1,2,3,4$ and 5 & $1517.0 \pm 1.31$ & 7.71 & $0.9573 * *$ & $<0.0001$ & 0.86778 & $206.2 \pm 5.05$ & $\mathrm{f}$ \\
\hline 58 & $1,2,3,4$ and 6 & $1516.9 \pm 1.25$ & 7.40 & $0.9394 * *$ & $<0.0001$ & 0.82385 & $202.5 \pm 4.87$ & $\mathrm{f}$ \\
\hline 59 & $1,2,3,5$ and 6 & $1513.7 \pm 1.10$ & 8.03 & $0.7867 * *$ & $<0.0001$ & 0.66589 & $197.3 \pm 4.75$ & $\mathrm{f}$ \\
\hline 60 & $1,2,4,5$ and 6 & $1514.3 \pm 1.13$ & 7.90 & $0.9376^{* *}$ & $<0.0001$ & 0.74202 & $195.9 \pm 4.61$ & $\mathrm{f}$ \\
\hline 61 & $1,3,4,5$ and 6 & $1515.6 \pm 1.47$ & 9.42 & $0.9603 * *$ & $<0.0001$ & 0.98039 & $200.1 \pm 4.67$ & $\mathrm{f}$ \\
\hline 62 & $2,3,4,5$ and 6 & $1515.7 \pm 1.38$ & 8.79 & $0.9637 * *$ & $<0.0001$ & 0.92008 & $197.0 \pm 4.70$ & $\mathrm{f}$ \\
\hline
\end{tabular}

${ }^{1}$ Number of leaves sampled from three branches per plant.

${ }^{2}$ Average number of thrips on 47 evaluations -15 plants for evaluation.

${ }^{3}$ Means number of thrips by same letter in the column differ by the Tukey test $(\mathrm{P}<0.01)$.

* Significant at $1 \%$ probability, and **Significant at $5 \%$ probability. 
TABLE 4- Mean number of thrips (larvae + adults), relative variance (RV), probability significance $(P)$, correlation coefficient $\left(r^{2}\right)$, sampling time, sampling cost and economic accuracy of two sampling methods in vineyards' inflorescences, Sugraone cultivar. Petrolina, PE, 2008 to 2010.

\begin{tabular}{|c|c|c|}
\hline Features & Beating flower in tray & Flower collection \\
\hline Density $^{1}($ Mean \pm SE) & $1.69 \pm 0.19 \mathrm{~b}$ & $5.48 \pm 0.86 \mathrm{a}$ \\
\hline Relative variance & 11.24 & 15.69 \\
\hline$P$ & 0.0001 & 0.0001 \\
\hline$r^{2}$ & $0.19 * *$ & $0.96 * *$ \\
\hline Sampling time ${ }^{2}(\mathrm{~min})$ & 11.13 & 37.42 \\
\hline Sampling $\operatorname{cost}^{3}(\mathrm{R} \$)$ & 4.62 & 63.76 \\
\hline Economic accuracy & 0.7993 & 0.1262 \\
\hline
\end{tabular}

${ }^{1}$ Average number of thrips on 300 inflorescences. Means followed by same letter within row do not differ by Tukey test (P>0.05).

${ }^{2}$ Sampling time in 10 plants and zig zag pathway.

${ }^{3}$ Sampling cost in 10 plants.

**Significant at $1 \%$ probability.

TABLE 5-Mean number (m) of of thrips (larvae + adults), variance $\left(s^{2}\right)$ and number of samples to estimate thrips' population density in vineyards, Sugraone cultivar, depending on the pre-determined precision levels. Petrolina, PE, 2008 to 2010.

\begin{tabular}{lccccccccccc}
\hline \multirow{2}{*}{ Samplings } & \multirow{2}{*}{$m$} & \multirow{8}{*}{$s^{2}$} & \multicolumn{1}{c}{ Precision levels (\%) } \\
\cline { 4 - 12 } & & & 10 & 15 & 20 & 25 & 30 & 35 & 40 & 45 & 50 \\
\hline Plants (leaves) & 15.3 & 50.9 & 42 & 19 & 10 & 7 & 5 & 3 & 3 & 2 & 2 \\
Inflorescences & 10.3 & 61.9 & 332 & 147 & 83 & 53 & 37 & 27 & 20 & 16 & 13 \\
\hline
\end{tabular}

TABLE 6- Relative variance (RV) and economic accuracy (EA) for sample sizes of inflorescences using simulated samplings for the average $(m)$ number of thrips (larvae + adults) in vineyards, cultivar Sugraone. Petrolina, PE, 2008 to 2010.

\begin{tabular}{|c|c|c|c|c|c|c|}
\hline \multirow{2}{*}{ Samples } & \multicolumn{3}{|c|}{ Flowers $40 \%$ opened } & \multicolumn{3}{|c|}{ Flowers $100 \%$ opened } \\
\hline & $m$ & $\mathrm{RV}$ & EA & $m$ & RV & EA \\
\hline \multicolumn{7}{|c|}{ 1st Production cycle } \\
\hline 10 & 3.4 & 22.9 & 0.95 & 5.0 & 24.0 & 0.90 \\
\hline 15 & 5.0 & 24.2 & 0.60 & 5.4 & 22.0 & 0.66 \\
\hline 20 & 2.8 & 24.7 & 0.44 & 6.6 & 21.3 & 0.51 \\
\hline 25 & 4.7 & 24.8 & 0.35 & 4.12 & 19.3 & 0.45 \\
\hline 30 & 4.1 & 24.6 & 0.29 & 7.0 & 20.6 & 0.35 \\
\hline 35 & 3.0 & 24.2 & 0.26 & 8.5 & 22.0 & 0.28 \\
\hline 40 & 4.2 & 19.6 & 0.28 & 8.0 & 22.7 & 0.24 \\
\hline \multicolumn{7}{|c|}{ 2nd Production cycle } \\
\hline 10 & 2.1 & 21.8 & 0.99 & 12.7 & 20.6 & 1.05 \\
\hline 15 & 2.9 & 22.3 & 0.65 & 13.4 & 17.2 & 0.84 \\
\hline 20 & 2.7 & 18.8 & 0.58 & 17.2 & 19.3 & 0.56 \\
\hline 25 & 2.9 & 14.2 & 0.61 & 14.8 & 12.1 & 0.72 \\
\hline 30 & 3.0 & 19.4 & 0.37 & 16.0 & 11.8 & 0.61 \\
\hline 35 & 2.9 & 16.9 & 0.37 & 15.5 & 11.9 & 0.52 \\
\hline 40 & 3.4 & 17.5 & 0.31 & 17.6 & 11.9 & 0.45 \\
\hline
\end{tabular}




\section{CONCLUSION}

Leaves in position 3 or 4 of branches located in the middle position of the plant are the most suitable in thrips population surveys. Leaves are a better sample unit to assess thrips (larvae + adults) in all phenological phases of the vine. Ten leaves should be sampled per hectare (accuracy 20\%).

Beating inflorescence is the proper technique for sampling larvae and adult thrips on vines, and 10 samples should be performed in 1.0 hectare, based on the relative variance and economic precision.

\section{ACKNOWLEDGMENTS}

The authors thank A.C. for helping with specimen identification and Embrapa Semi-Arid and Instituto Federal de Educação, Ciência e Tecnologia do Sertão Pernambucano, for allowing the execution of this research. They are grateful to the Coordination for the Improvement of Higher Level Personnel (CAPES) for providing the first author's scholarship, and to the National Council for Scientific and Technological Development (CNPq) for grants in research productivity for J.V.O., J.E.M.O. and J.B.T. They thank Dra. Renata C. Monteiro and Dr. Adriano Cavalleri for thrips identification.

\section{REFERENCES}

ABDULLAH, Z.S., GREENFIELD, B.P.J.; FICKEN, K.J.; TAYLOR, J.W.D., WOOD, M.; BUTT, T.M. A new attractant for monitoring western flower thrips, Frankliniella occidentalis in protected crops. Springerplus, Switzerland, v.24, n.4, p.1-9, 2015.

ALIAKBARPOUR, H.; RAWI, C.S.M.D. Diurnal activity of four species of thrips (Thysanoptera: Thripidae) and efficiencies of three nondestructive sampling techniques for thrips in mango inflorescences. Journal of Economic Entomology, Lanham, v.103, p.631-640, 2010.

ARCE-FLORES, J.; LÓPEZ-MARTÍNEZ, V.; GAONA-GARCÍA, A. Fluctuación poblacional y distribución de Frankliniella occidentalis (Pergande) (Thysanoptera: Thripidae) en nardo en Morelos, México. Acta Agrícola y Pecuaria, Cuenarvaca, v.1, n.1, p.37-42, 2014.
BACCI, L.; PICANÇO, M.C.; MOURA, M.F.; SEMEÃO, A.A.; FERNANDES, F.L.; MORAIS, E.G.F. Sampling plan for thrips (Thysanoptera: Thripidae) on cucumber. Neotropical Entomology, Londrina, v.37, p.582-590, 2008.

BOTTON, M.; MENEZES-NETTO, A.C.; ARIOLII, C.J.; OLIVEIRA, J.E de M. Maneio integrado de insetose ácaros-praga em uvasde mesa no Brasil. Informe Agropecuário, Belo Horizonte, v.36, n.289, p.57-69, 2015.

BOTTON, M.; NONDILlO, A., ZART, M.; PINENT, S.; GENTA, W. Avaliação de inseticidas para o controle de Frankliniella rodeos (Moulton, 1933) (Thysanoptera: Thripidae) em uva de mesa no Brasil. Boletín de Sanidad Vegetal Plagas, Madrid, v.33, p.575-580, 2007.

CARRIZO, P.I.; KLASMAN, R. Muestreo para el seguimiento poblacional de Frankliniella occidentalis (Pergande, 1985) (Thysanoptera: Thripidae) en cultivo de Dianthus caryophyllus (Cariophyllaceae) en invernadero. Entomotropica, Maracay, v.17, p.7-14, 2002.

DAKSHINA, R. S.;KUMAR, V. Biological response of chilli thrips, Scirtothrips dorsalis Hood (Thysanoptera: Thripidae), to various regimes of chemical and biorational insecticides. Crop Protection, Guildford, v. 29, n. 11, p. 1241-1247, 2010.

GONZÁLEZ, R. El trips de California y otros tisanopteros de importancia hortifruticola em Chile (Thysanoptaera: Thripidae). Santiago: Universidad de Chile, 1999. 143p. (Série Ciências Agronômicas)

GUSMÃO, M.R.; PICANÇO, M.C.; ZANUNCIO, J.C.; SILVA, D.J.H.; BARRIGOSSI, J.A.F. Standardised sampling plan for Bemisia tabaci (Homoptera: Aleyrodidae) in outdoor tomatoes. Scientia Horticulturae, Amsterdam, v.103, p.403412, 2005.

HAJI, F.N.P.; ALENCAR, J.A. Pragas da videira e alternativas de controle. In: LEÃO, P.C.S.; SOARES, J.M. (Ed.). A vitivinicultura no semi-árido brasileiro. Petrolina: Embrapa Semi-Árido, 2000. p.273-291. 
HAJI, F.N.P.: OLIVEIRA, J.E.M.; ALENCAR, J.A.; GERVÁSIO, R.C.R.G.; SANTOS, V.F.C.; MOREIRA, A.N. Pragas e alternativas de controle. In: SOARES J.M.; LEÃO, P.C.S. (Ed.). A vitivinicultura no semiárido brasileiro. Brasília: Embrapa Informação Tecnológica, 2009. p.513539.

HAJI, F.N.P.; ALENCAR, J.A.; BARBOSA, F.R. Pragas. In: LIMA, M.F.; MOREIRA, W.A. (Ed.). Uva de mesa: fitossanidade. Brasília: Embrapa Informação Tecnológica, 2002. p.53-63. (Frutas do Brasil, 14).

HAJI, F.N.P.; MOREIRA, A.N.; ALENCAR, J.A; BARBOSA, F.R. Monitoramento de pragas na cultura da videira. Petrolina: Embrapa Semi-Árido, 2001. 29p. (Documentos, 162).

KAPLAN, M.; BAYHAN, E.; ATAKAN, E. Determination of Thysanoptera species, their seasonal abundance and distribution in vineyard areas of Mardin Province. Turkish Bulletin of Entomology, Izmir, v.6, n.2, p.161-168, 2016.

KOGAN, M. Integrated pest management: historical perspectives and contemporary developments. Annual Review Entomology, Palo Alto, v.43, v.243$270,1998$.

KOGAN, M.; HERZOG, D.C. Sampling methods in soybean entomology. New York: Springer-Verlag, 1980. 587p.

KOGEL, W.J.; BALKEMA-BOOMSTRA, A.; VAN DER HOEK, M.; MOLLEMA, C. Resistance to Western flower thrips in greenhouse cucumber: effect of leaf position and plant age on thrips reproduction. Euphytica, Dordrecht, v.94, p.63-67, 1997a.

KOGEL, W.J.; VAN DER HOEK, M.; MOLLEMA, C. Oviposition preference of western flower thrips for cucumber leaves from different positions along the plant stem. Entomologia Experimentalis et Applicata, Dordrecht, v.82, p.283-288, 1997 b.

LEÃO, P.C.S.; RODRIGUES, B.L. Manejo da copa. In: LEÃO, P.C.S.; SOARES, J.M. (Ed.). A vitivinicultura no semi-árido brasileiro. Petrolina: Embrapa Semi-Árido, 2000 p. 293-348.
LOPES, R.B.; TAMAI, M.A.; ALVES, S.B.; SILVEIRA NETO, S.; SALVO, S. Occurence of thrips on niagara table grape and its control with the insecticides thiacloprid and methiocarb associated with Metarhizium anisopliae. Revista Brasileira de Fruticultura, Jaboticabal, v.24, p.269-272, 2002.

MATEUS, C.; ARAÚJO, J.; MEXIA, A. Frankliniella occidentalis (Thysanoptera: Thripidae) in spray-type carnations: spatial distribution analysis. Boletín de Sanidad Vegetal Plagas, Madrid, v.31, p.47-57, 2005.

MONTEIRO, R.C. The Thysanoptera fauna of Brasil In: MARULLO, R.; MOUND L.A. (Ed.). Thrips and Tospoviruses. In: INTERNATIONAL SYMPOSIUM ON THYSANOPTERA, 7., 2002. Proceedings... Canberra: Australian National Insect Collection, 2002. p.325-340.

MONTEIRO, R.C.; MOUND, L.A., ZUCCHI, R.A. Espécies de Frankliniella (Thysanoptera: Thripidae) de importância agrícola no Brasil. Neotropical Entomology, São Paulo, v.1, p.65-72, 2001.

MOREIRA, A.N.; VARGAS, J.V.; OLIVEIRA, J.E.M., OLIVEIRA, A.C., SOUZA, I.D. Variação sazonal de espécies de tripes em videira de acordo com sistemas de manejo e fases fenológicas. Pesquisa Agropecuária Brasileira, Brasília, DF, v.47, n.3, p.328-335, 2012.

MOREIRA, A.N.; VARGAS, J.V.; OLIVEIRA, J.E.M., SOUZA, G.M.M., BREDA, M.O. Injuries caused by Frankliniella spp. (Thysanoptera: Thripidae) on seedless grapes. Ciência e Agrotecnologia, Lavras, v.38, n.4, p.328-334, 2014.

MOURA, M.S.B.; TEIXEIRA, A.H.C.; SOARES J.M. Exigências climáticas. In: SOARES, J.M.; LEÃO, P.C.S. (Ed.). A vitivinicultura no Semiárido brasileiro. Brasília: Embrapa Informação Tecnológica, 2009. p. 35-69.

MUJICA, M.V.; SCATONI, I.; FRANCO, J.; NÚÑEZ, S.; BENTANCOURT, C. Fluctuación poblacional de Frankliniella occidentalis (Pergande) (Thysanoptera: Thripidae) en Vitis vinifera L. cv. Italia en la zona sur de Uruguay. Boletín de Sanidad Vegetal. Plagas, Madrid, v.33, p.457-467, 2007. 
OLIVEIRA, J.E.M.; LOPES, P.R.C.; HAJI, F.N.P.; MOREIRA, A.N.; MIRANDA, J.R. Produção integrada de uva no Vale do São Francisco. In: NASSER, L.C.B. (Org.). Produção integrada no Brasil: agropecuária sustentável alimentos seguros. Brasília: Mapa/ACS, 2009. p.913-934.

PARAJULE, M.N.; SHRESTHA, R.B.; LESER, J.F. Sampling methods, dispersion patterns, and fixed precision sequential sampling plans for western flower thrips (Thysanoptera: Thripidae) and cotton fleahoppers (Hemiptera: Miridae) in cotton. Journal Economic Entomology, Lanhan, v.99, p.568-577, 2006.

PEDIGO, L.P.; BUNTIN, G.D.; BECHINSKI, E.J. Flushing technique and sequential-count plan for green cloverworm (Lepidoptera: Noctuidae) moths in soybeans. Environmental Entomology, College Park, v.11, p.1223-1228, 1982.

PEDIGO, L.P.; RICE, M.E. Entomology and pest management. $6^{\text {th }}$ ed. New Jersey: Upper Saddle River, 2009. 784p.

PIZZOL, J.; NAMMOUR, D.; HERVOUET, P.; BOUT, A. Comparison of two methods of monitoring thrips populations in a greenhouse rose crop. Journal of Pest Science, Berlin, v.83, p.191-196, 2010.
SAS INSTITUTE. SAS User's Guide: statistics version 8 for Windows. Cary, 2001.

SEAL, D.R.; CIOMPERLIK, M.A.; RICHARDS, M.L.; KLASSEN, W. Distribution of chilli thrips, Scirtothrips dorsalis (Thysanoptera: Thripidae), in pepper fields and pepper plants on st. Vincent. Florida Entomologist, Winter Haven, v.89, p.1311320, 2006.

SEDARATIAN, A.; FATHIPOUR, Y.; TALEBI, A.A.; FARAHANI, S. Population density and spatial distribuition pattern of Thrips tabaci (Thysanoptera: Thripidae) on different soybean varieties. Journal of Agricultural Science and Technology, Tehran, v. 12, v.275-288, 2010.

SOUTHWOOD, T.R.E. Ecological methods. $2^{\text {nd }}$ ed. New York: John Wiley \& Sons, 1978. 525p.

SOUVIK SEN, S.K.P.; SUIAM, M.L. Is the use of yellow sticky trap detrimental to natural enemy complex of tea pests? American-Eurasian Journal of Agricultural \& Environmental Sciences, Faisalabad, v.16, n.9, p.1597-1601, 2016. 